\title{
Correction to: Burden of migraine and unmet needs from the patients' perspective: a survey across 11 specialized headache clinics in Korea
}

\author{
Byung-Kun Kim", Min Kyung Chu ${ }^{2}$, Soo Jin Yu ${ }^{3}$, Grazia Dell'Agnello ${ }^{4}$, Jeong Hee Han ${ }^{3}$ and Soo-Jin Cho ${ }^{5^{*}}$
}

\section{Correction to: The Journal of Headache and Pain 22, 45 (2021)} https://doi.org/10.1186/s10194-021-01250-6

Following the publication of the original article [1], we were notified of two errors, in the legend for Fig. 3 and in the author details.

1. Fig. 3 legend: 'Results are presented as mean percentage of respondents.' should read 'Results are presented as percentage of respondents.' (the word 'mean' needs to be removed)

2. Author details: affiliation 4 should be 'Eli Lilly and Company, Sesto Fiorentino (FI), Italy' instead of 'Eli Lilly and Company, Indianapolis, IN, USA'.

The original article has been corrected.

\section{Author details}

${ }^{1}$ Department of Neurology, Nowon Eulji Medical Center, Eulji University

School of Medicine, Seoul, South Korea. ${ }^{2}$ Department of Neurology,

Severance Hospital, Yonsei University School of Medicine, Seoul, South Korea.

${ }^{3}$ Lilly Korea Ltd., Seoul, South Korea. ${ }^{4}$ Eli Lilly and Company, Sesto Fiorentino,

(FI), Italy. ${ }^{5}$ Department of Neurology, Dongtan Sacred Heart Hospital, Hallym

University College of Medicine, Hwaseong, South Korea.

Published online: 11 June 2021

\section{Reference}

1. Kim BK et al (2021) Burden of migraine and unmet needs from the patients' perspective: a survey across 11 specialized headache clinics in Korea. J Headache Pain 22:45. https://doi.org/10.1186/s10194-021-01250-6

The original article can be found online at https://doi.org/10.1186/s10194021-01250-6.

* Correspondence: dowonc@naver.com

${ }^{5}$ Department of Neurology, Dongtan Sacred Heart Hospital, Hallym University College of Medicine, Hwaseong, South Korea

Full list of author information is available at the end of the article

C C The Author(s). 2021 Open Access This article is licensed under a Creative Commons Attribution 4.0 International License, which permits use, sharing, adaptation, distribution and reproduction in any medium or format, as long as you give appropriate credit to the original author(s) and the source, provide a link to the Creative Commons licence, and indicate if changes were made. The images or other third party material in this article are included in the article's Creative Commons licence, unless indicated otherwise in a credit line to the material. If material is not included in the article's Creative Commons licence and your intended use is not permitted by statutory regulation or exceeds the permitted use, you will need to obtain permission directly from the copyright holder. To view a copy of this licence, visit http://creativecommons.org/licenses/by/4.0/ The Creative Commons Public Domain Dedication waiver (http://creativecommons.org/publicdomain/zero/1.0/) applies to the data made available in this article, unless otherwise stated in a credit line to the data. 